\title{
SERUM LIPIDS IN HYPOTHYROID CHILDREN: EFFECT OF DISEASE AND LEVOTHYROXINE REPLACEMENT THERAPY
}

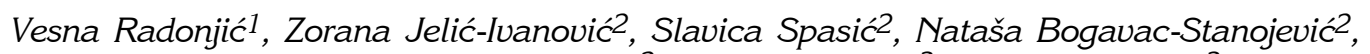 \\ Vesna Spasojević-Kalimanouska², Božidar Bojović3, Rajko Milunović ${ }^{3}$ \\ ${ }^{1}$ Health Centre of Kotor, Kotor \\ 2Institute of Medical Biochemistry, University School of Pharmacy, Belgrade \\ IInstitute of Children's Diseases, Clinical Centre of Podgorica, Podgorica
}

\begin{abstract}
Summary: Hypothyroidism is associated with dislipidaemia and an increased risk of atherosclerosis. The aim of this study was to examine the effect of disease and long-term levothyroxine replacement therapy on serum lipids in hypothyroid children. We measured concentrations of total cholesterol, HDL-cholesterol, LDL-cholesterol, triglycerides and thyroid-stimulating hormone in serum samples of 58 children with hypothyroidism (before and after therapy) and in 100 healthy controls. LDL-C and TC values were most markedly affected by the hypothyroid state. The values in the patients were on the average of $100 \%$ (LDL-C) and $54 \%$ (TC) higher than in the healthy controls. This finding is accordance with the known fact that LDL clearance is slower in hypothyroidism. TG concentrations were slightly higher $(p<0.05)$ and HDL-C lower $(p<0.02)$, but only in some age groups of patients. The effect of long-term L-T 4 replacement on LDL-C and TC was quantitatively most pronounced. The values obtained in patients after therapy were markedly lower than before therapy and did not differ significantly from the values found in the corresponding age groups of healthy children. Significantly lower concentrations of HDL-C and TG after L-T 4 administration were found only in children aged from 10 to 15 years. When we compared the lipid-lowering effect of L- $\mathrm{T}_{4}$ replacement therapy in normometabolic versus hypometabolic patients, we obtained a significantly greater effect on TC and LDL-C values in the normometabolic than in hypometabolic group $(\mathrm{p}<0.01)$. TC and LDL-C concentrations obtained in the L- $\mathrm{T}_{4}$ treated patients correlated well with the corresponding TSH levels ( $r=0.770$ and 0.725 , respectively).
\end{abstract}

Key words: thyroid disease, secondary dyslipidaemia, cholesterol, replacement therapy.

\section{Introduction}

Thyroid hormones (3,5,3'-triiodothyronine; $\mathrm{T}_{3}$ and thyroxine; $\mathrm{T}_{4}$ ) play an important role in the regulation of cell metabolism. The biological function of $\mathrm{T}_{3}$ is mediated through thyroid hormone receptors (TRs), which bind to specific DNA segments (thyroid hormone response elements, TREs) in the regulatory regions of target genes, thus altering gene expression (1). Subsequently, thyroid hormone deficiency is characterized by major metabolic disturbancies, including lipid metabolism.

Address for correspondence

Vesna Radonjić

Dom zdravlja Kotor

85330 Kotor

e-mail: diminino@cg.yu
The impact of thyroid hormones on lipid levels is primarily mediated through activation of promoter regions of the low-density lipoprotein (LDL) receptor, 3-hydroxy-3-methylglutaryl coenzyme A (HMG-CoA) reductase, cholesteryl-ester transfer protein (CETP) and hepatic lipase (HL) genes (2 5). Hypothyroidism is a well-established cause of secondary dyslipidaemia and the increased risk of atherosclerosis (6). It is characterized by hypercholesterolaemia and a marked increase of LDL. This is caused by a markedly decreased fractional clearance of LDL particles because of a reduced number of LDL receptors in the liver. However, conflicting results were obtained in different studies

Abbreviations: L T4, levothyroxine; TC, cholesterol, HDL-C, HDL-cholesterol, LDL-C, LDL-cholesterol, TG, triglycerides; $\mathrm{TSH}$, thyroid-stimulating hormone 
concerning HDL-C levels in hypothyroidism: HDL-C was reported to be normal $(7)$, increased $(810)$ or decreased (11).

The influence of different genetic and environmental factors is very important in the regulation of lipid and lipoprotein metabolism. Therefore, studies investigating normal or pathological lipid metabolism have to be conducted in different populations. In the present study, we investigated the effect of disease and long-term $\mathrm{L}-\mathrm{T}_{4}$ replacement therapy on serum lipid profile in hypothyroid children from Montenegro. Serum concentrations of total cholesterol (TC), HDL-cholesterol (HDL-C), LDL-cholesterol (LDL-C) and triglycerides (TG) were measured in the patients before and after $\mathrm{L}-\mathrm{T}_{4}$ replacement. The same data sets were obtained for a group of 100 healthy children, matched according to age and gender. We also compared the extent of the $\mathrm{L}-\mathrm{T}_{4}$ effect on serum lipids found in patients divided according to their metabolic status and TSH levels.

\section{Materials and Methods}

\section{Study population}

Serum lipid profile was assessed in a population of 58 hypothyroid children (22 boys and 36 girls), attending the Institute of Children's Diseases, Clinical Centre of Podgorica. The patients were aged from 2 months to 18 years, since the age at which clinically overt hypothyroidism appeared depended on the severity of the defect. Analyses were performed on two occasions: (1) when diagnosis of hypothyroidism was established and (2) at follow-up examination, after long-term L- $\mathrm{T}_{4}$ replacement therapy. The control group consisted of 100 healthy children, matched according to age and gender.

Metabolic status of hypothyroid children was assessed by endocrinologist at follow-up examination, based on characteristic clinical signs and symptoms, and the patients were thus classified as normo-, hypoor hypermetabolic.

\section{Reagents and Procedures}

Serum lipid profile analyses were carried out in blood samples collected after a 12-h fasting period. Serum was separated by centrifugation at $3000 \mathrm{rpm}$ and fresh samples were analyzed. TC and TG were measured by standard enzymatic methods, using commercial reagent kits from Randox Laboratories Ltd. (Crumlin, United Kingdom). HDL-C was assayed by the same enzymatic method used for the TC measurement, after precipitation with phosphotungstic acid in the presence of magnesium ions. The concentration of LDL-C was calculated with the Friedewald's formula (12). TSH levels were measured by time-resolved fluoroimmunoassay by DELFIA ${ }^{*}$ hTSH reagent kit from Wallac Oy (Turku, Finland).

\section{Statistical Methods}

All values were expressed as means \pm SD. The patients and healthy controls were divided in five age groups. Comparison of serum lipid values between patients and control subjects, as well as between the values obtained in patient groups before and after therapy, was performed by Student's t-test. The significance of the difference between the lipid concentrations found in individual patients before and after $\mathrm{L}-\mathrm{T}_{4}$ replacement was assessed by using the paired Student $\mathrm{t}$-test. The concentrations of serum lipids in the treated patients were also correlated with the corresponding TSH levels by linear regression analysis.

\section{Results}

The concentrations of serum lipids obtained in children with hypothyroidism before and during longterm L- $\mathrm{T}_{4}$ replacement therapy as well as in healthy controls are shown in Table I. The LDL-C and TC values were most markedly affected by hypothyroid state: the values in the patients were on the average of $100 \%$ (LDL-C) and 54\% (TC) higher than in the healthy children. TG concentrations were slightly higher $(\mathrm{p}<0.05)$ and HDL-C lower $(\mathrm{p}<0.02)$, but only in some age groups.

The effect of long-term L- $\mathrm{T}_{4}$ replacement on LDL$-C$ and TC was quantitatively most pronounced: the values obtained in patients after therapy were markedly lower than before therapy and did not differ significantly from the values found in the corresponding age groups of healthy children. Lower concentrations of HDL-C were obtained after $\mathrm{L}_{-} \mathrm{T}_{4}$ replacement, but the differences between the values found before and after therapy were statistically significant only in children aged from 10 to 15 years $(p<0.05)$. In the same age group of patients, replacement therapy induced a significant decrease of serum TG concentrations $(\mathrm{p}<0.005)$.

In order to compare the lipid-lowering effect of long-term L- $\mathrm{T}_{4}$ replacement therapy in normometabolic versus hypometabolic patients, the concentrations of serum lipids in patients under long-term therapy were expressed as percents of the respective baseline values before therapy (Table II). Marked effect of L-T4 administration of serum TC and LDL-C levels were found not only in normometabolic, but also in hypometabolic patients. However, significantly greater effect on TC and LDL-C values was found in the normometabolic than in hypometabolic group $(p<0.01)$. The decrease in HDL-C levels induced by long-term L$-\mathrm{T}_{4}$ administration was significant in both groups of patients $(p<0.01)$. The drug effects mentioned above can be most clearly seen from data presented in Figure 1, where the individual TC, HDL-C, LDL-C and TG levels obtained in the same patients before and after therapy, are shown. 
Table I Concentrations of serum lipids in healthy children (I), children with hypothyroidism before therapy (II) and during long-term L-T4 replacement therapy (III) (n.s. - not significant)

\begin{tabular}{|c|c|c|c|c|c|c|c|c|c|}
\hline $\begin{array}{l}\text { Age } \\
\text { (years) }\end{array}$ & $\mathrm{N}_{\mathrm{I}}$ & $(\overline{\mathrm{x}} \quad \mathrm{I} \mathrm{SD})$ & $\mathrm{N}_{\text {II }}$ & $(\overline{\mathrm{x}} \stackrel{\mathrm{II}}{\mathrm{SD}})$ & $\mathrm{N}_{\text {III }}$ & $(\overline{\mathrm{x}} \stackrel{\mathrm{III}}{\mathrm{SD}})$ & ${ }_{\text {I II }}^{\mathrm{P}}$ & ${ }_{\text {II III }}^{\mathrm{P}}$ & I \\
\hline \multicolumn{10}{|c|}{ CHOLESTEROL, mmol/L } \\
\hline 0.11 & 20 & 3.120 .48 & 17 & 6.270 .78 & & & $<0.001$ & & \\
\hline 1.15 & 20 & 3.740 .67 & 14 & $5.60 \quad 1.18$ & 8 & 3.840 .65 & $<0.001$ & $<0.001$ & n.s. \\
\hline 5.110 & 20 & 3.770 .48 & 8 & 5.430 .41 & 10 & 3.940 .78 & $<0.001$ & $<0.001$ & n.s. \\
\hline 10.115 & 20 & 3.920 .57 & 13 & 5.871 .16 & 20 & $3.40 \quad 0.43$ & $<0.01$ & $<0.001$ & $<0.01$ \\
\hline 15.118 & 20 & 3.990 .53 & 6 & $5.10 \quad 0.52$ & 18 & 4.230 .90 & $<0.01$ & $<0.05$ & n.s. \\
\hline \multicolumn{10}{|c|}{ TRIGLYCERIDES, mmol/L } \\
\hline 0.11 & 20 & 0.760 .37 & 17 & 0.780 .21 & & & n.s. & & \\
\hline 1.15 & 20 & $0.67 \quad 0.24$ & 14 & 1.010 .46 & 8 & $0.68 \quad 0.34$ & $<0.05$ & n.s. & n.s. \\
\hline 5.110 & 20 & 0.780 .33 & 8 & 0.840 .16 & 10 & 1.020 .74 & n.s. & n.s. & n.s. \\
\hline 10.115 & 20 & 0.980 .54 & 13 & 1.090 .31 & 20 & 0.810 .16 & n.s. & $<0.005$ & n.s. \\
\hline 15.118 & 20 & 0.820 .19 & 6 & 1.110 .44 & 18 & 1.180 .39 & $<0.05$ & n.s. & $<0.001$ \\
\hline \multicolumn{10}{|c|}{ HDL-CHOLESTEROL, mmol/L } \\
\hline 0.11 & 20 & 1.370 .38 & 17 & 1.420 .26 & & & n.s. & & \\
\hline 1.15 & 20 & 1.360 .26 & 14 & 1.350 .35 & 8 & 1.260 .35 & n.s. & n.s. & n.s. \\
\hline 5.110 & 20 & 1.390 .36 & 8 & $1.40 \quad 0.24$ & 10 & 1.300 .40 & n.s. & n.s. & n.s. \\
\hline 10.115 & 20 & 1.460 .33 & 13 & $1.43 \quad 0.27$ & 20 & 1.240 .21 & n.s. & $<0.05$ & $<0.02$ \\
\hline 15.118 & 20 & 1.490 .30 & 6 & 1.090 .34 & 18 & 1.110 .23 & $<0.02$ & n.s. & $<0.001$ \\
\hline \multicolumn{10}{|c|}{ LDL-CHOLESTEROL, $\mathrm{mmol} / \mathrm{L}$} \\
\hline 0.11 & 20 & 1.400 .65 & 17 & 4.500 .92 & & & $<0.001$ & & \\
\hline 1.15 & 20 & 2.080 .73 & 14 & 3.801 .08 & 8 & 2.280 .56 & $<0.001$ & $<0.005$ & n.s. \\
\hline 5.110 & 20 & 2.020 .51 & 8 & 3.640 .26 & 10 & $2.18 \quad 0.74$ & $<0.001$ & $<0.001$ & n.s. \\
\hline 10.115 & 20 & $2.02 \quad 0.38$ & 13 & 3.941 .08 & 20 & 1.780 .38 & $<0.001$ & $<0.001$ & n.s. \\
\hline 15.118 & 20 & 2.120 .54 & 6 & 3.500 .59 & 18 & 2.580 .94 & $<0.001$ & $<0.05$ & n.s. \\
\hline
\end{tabular}

Table II Comparison of lipid-lowering effect of L-T4 replacement therapy in normometabolic versus hypometabolic patients. The concentrations of serum lipids in patients under long-term therapy are shown as percents of the respective baseline values before therapy (n.s. - not significant)

\begin{tabular}{|l|c|c|c|c|c|}
\hline & \multicolumn{2}{|c|}{$\begin{array}{c}\text { Normometabolic } \\
(\mathrm{N}=35)\end{array}$} & \multicolumn{2}{c|}{$\begin{array}{c}\text { Hypometabolic } \\
(\mathrm{N}=17)\end{array}$} \\
$\begin{array}{l}\text { (normo vs. } \\
\text { hypometabolic) }\end{array}$ \\
\hline Cholesterol & $\%$ & $\mathrm{p}$ & $\%$ & $\mathrm{p}$ & $<0.01$ \\
\hline Triglycerides & 62.1 & $<0.01$ & 94.9 & $<0.01$ & n.s. \\
\hline HDL-cholesterol & 97.8 & n.s. & 130.2 & n.s. & n.s. \\
\hline LDL-cholesterol & 91.0 & $<0.01$ & 87.9 & $<0.01$ & $<0.01$ \\
\hline
\end{tabular}

We assessed the correlation between the concentrations of the measured serum lipid profile parameters and the corresponding TSH levels in hypothyroid children receiving long-term ${\mathrm{L}-\mathrm{T}_{4}}_{4}$ therapy. Good correlation was obtained between the TC and TSH values (y
$=3.282+0.162 x ; r=0.770 ;$ Figure 2$)$, as well as between the LDL-C and TSH $(y=1.689+0.149 x ; r=0.725)$ values. When the correlations of HDL-C vs. TSH and TG vs. TSH were tested, low correlation coefficients were obtained $(r=0.122$ and $r=0.399$, respectively). 

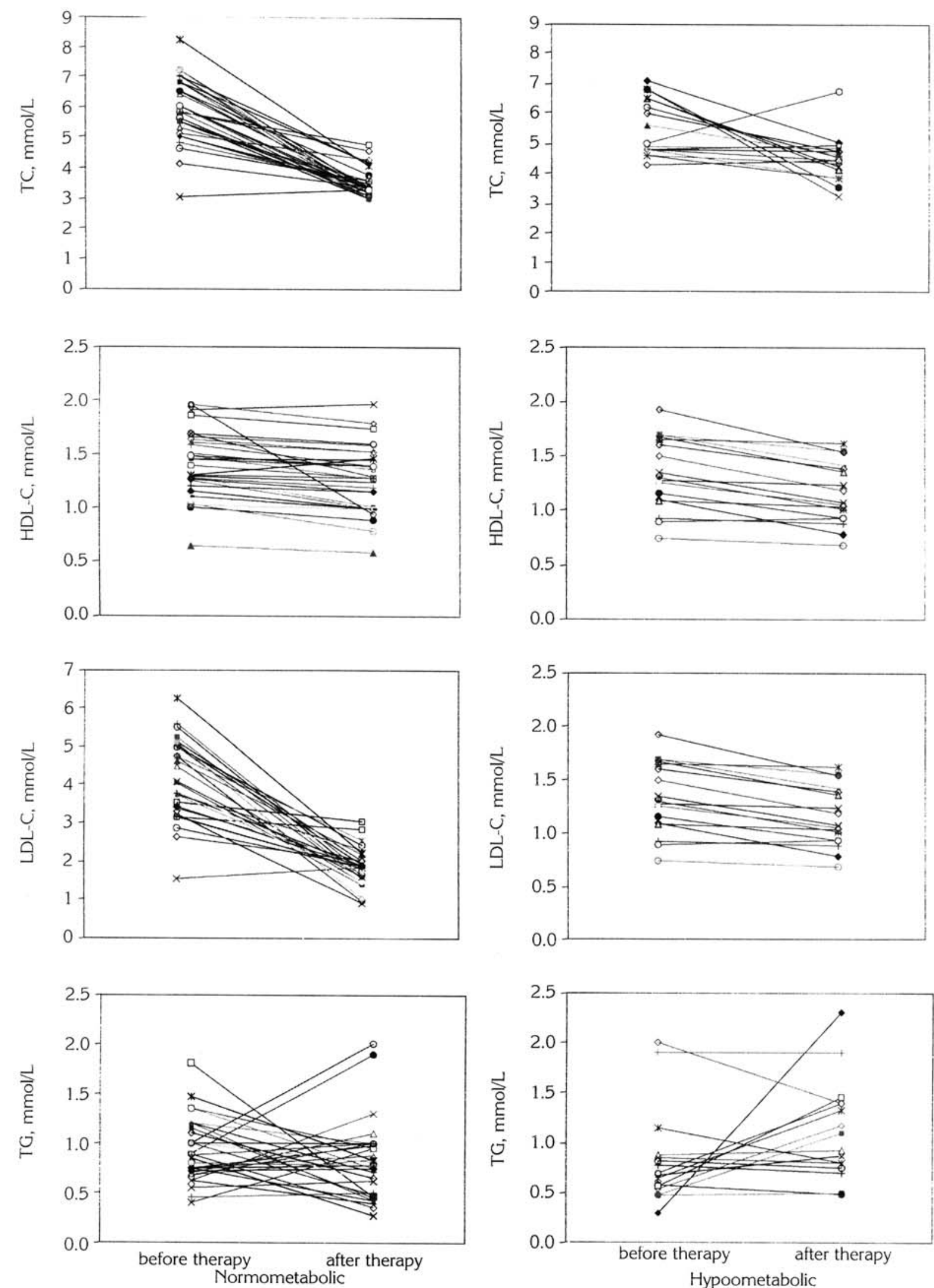

Figure 1. Effect of long-term L- $\mathrm{T}_{4}$ replacement therapy on serum lipids in normometabolic and hypometabolic children 

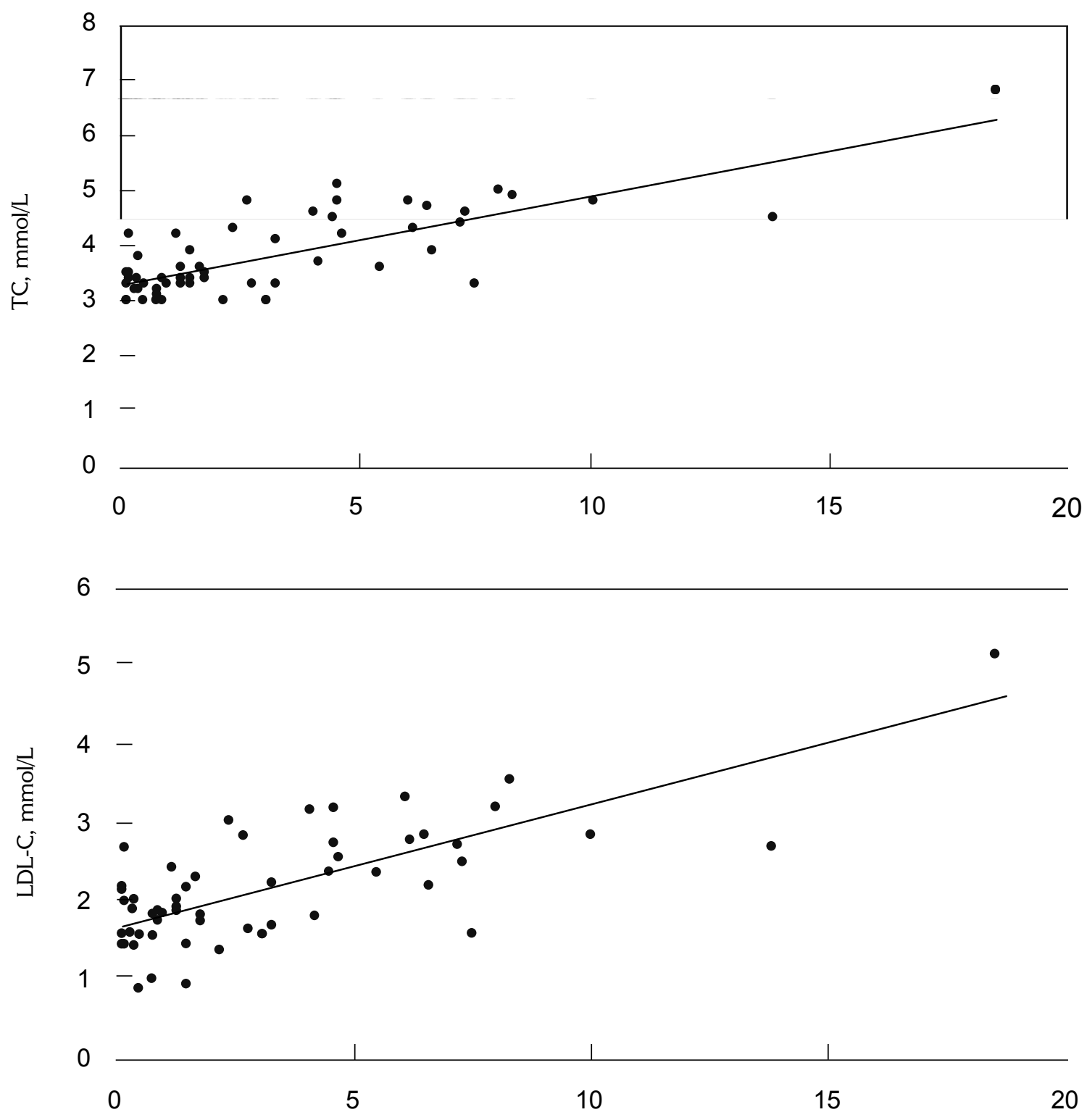

Figure 2. Correlation between serum TC and TSH levels $(y=3.282+0.162 x ; r=0.770)$ and between LDL-C and TSH $(y=1.689+0.149 x ; r=0.725)$ in hypothyroid children receiving long-term $L-T_{4}$ therapy

\section{Discussion}

Dyslipidaemia caused by thyroid hormone deficiency is associated with the increased risk of atherosclerosis (6). Serum lipid profile in hypothyroidism is characterized by hypercholesterolaemia with a marked increase in LDL-cholesterol levels, but different results were obtained in different studies concerning HDL-C levels (7 11).

The patients included in this study were aged from 2 months to 18 years, since the age at which clinically overt hypothyroidism appeared was dependent on the severity of the disease. As serum lipid profile change with age, TC, HDL-C, LDL-C and TG concentrations obtained in the patients before $\mathrm{L}_{-} \mathrm{T}_{4}$ administration were compared with the corresponding values found in the age-matched healthy controls (Table I). TC and LDL-C values were most markedly affected by hypothyroid state: the values in the patients were on the average of $54 \%$ (TC) and $100 \%$ (LDL-C) higher than in healthy children. In most patients, this increase was sufficient to reach high-risk TC and LDL-C levels: $>5.15 \mathrm{mmol} / \mathrm{L}$ and $>3.37 \mathrm{mmol} / \mathrm{L}$, respectively (13). 
The effect of the disease on serum TC and LDL$-C$ concentrations was reversed by $\mathrm{L}_{-} \mathrm{T}_{4}$ treatment: the values obtained in the treated patients were markedly lower than the levels before $\mathrm{L}_{-} \mathrm{T}_{4}$ administration, and did not differ significantly from the corresponding values found in healthy children (Table I). Our findings agree with the results of other authors: hypercholesterolaemia and a marked increase of LDL-C are typically found in hypothyroid individuals $(2,6,8,9,14)$. It is well-known that the transcription of the HMG-CoA reductase gene is activated by thyroid hormones (2 5). As HMG-CoA reductase is the rate-limiting enzyme in the cholesterol synthesis pathway, lower cholesterol synthesis rate is expected in hypothyroidism. However, LDL-receptor gene is also one of the thyroid hormone target genes. Although cholesterol synthesis is impaired in hypothyroid state, this effect is overwhelmed by a markedly decreased fractional clearance of LDL particles because of a reduced number of LDL receptors in the liver $(2,3)$. This leads to LDL accumulation and high serum TC and LDL-C concentrations. Our finding that the cholesterol-lowering effect of L-T4 replacement therapy was significantly greater in normometabolic than in hypometabolic patients (Table II, Figure 1) can also be explained in terms of the mechanism described above: L-T4 administration fully restored LDL-receptor synthesis in normometabolic, but uncompletely in hypometabolic patients. In normometabolic children, TC and LDL-C concentrations after L- $\mathrm{T}_{4}$ replacement were in the range of recommended values (Figure 1) : $<4.4 \mathrm{mmol} / \mathrm{L}$ and $<2.85 \mathrm{mmol} / \mathrm{L}$, respectively (13). However, this could be achieved only in a minority of hypometabolic children.

TC and LDL-C concentrations obtained in the patients treated with $\mathrm{L}-\mathrm{T}_{4}$ correlated well with the corresponding TSH levels (Figure 2). Significant associations with TSH were reported for TC and LDL-C by other authors as well $(3,15)$ and have been variously attributed to suboptimal therapy and/or an abnormal setting of the T4 negative feedback control of pituitary TSH secretion (16 18). Further investigations are needed to explain which of the two mechanisms caused the persistence of elevated TSH values in some of the $\mathrm{L}^{-} \mathrm{T}_{4}$-treated children included in this study.

In the oldest group (15.1 18 years), HDL-C was significantly lower in the patients, but the patients/controls differences were not significant in other age groups. Conflicting results appeared in the literature concerning HDL levels in hypothyroidism. Verdugo et al. (7) found normal HDL-C values in hypothyroid women, Agdeppa et al. (11) reported decreased values in hypothyroidism, whereas the increase of HDL-C concentration was observed in several studies (8 10). In any case, the influence of thyroid hormone deficiency on serum HDL-C levels is not so marked as the effect on LDL-C and TC values. However, there is evidence that the composition of HDL particles is altered in hypothyroid state $(4,5)$. The effect is mediated through the regulation of CETP and HL genes expression by thyroid hormones. Tan et al (5) have shown for the first time that the concentration of HDL particles containing only apo A-I (LpA-I) was increased in hypothyroidism. As LPA-I is more antiatherogenic than LPA-II (19), its increase in hypothyroid individuals might partly counteract the harmful effect of raised LDL-C.

Slightly higher TG concentrations were found in patients than in healthy children, but only in some age groups, whereas no significant differences were found in the others (Table I). This is in agreement with the findings of other authors: TG and VLDL levels in hypothyroidism are normal or sometimes elevated (2), because of decreased lipoprotein lipase activity and a consequent slower rate of VLDL catabolism (20). However, the extent of this effect is not always sufficient to produce a statistically significant difference between the TG values found in healthy and hypothyroid individuals, or before and after ${\mathrm{L}-\mathrm{T}_{4}}_{4}$ treatment.

In conclusion, hypothyroidism caused a marked increase in serum TC and LDL-C concentrations in the population of children from Montenegro, reaching the values associated with high risk of atherosclerosis. Long-term $\mathrm{L}-\mathrm{T}_{4}$ replacement therapy reversed this effect, especially in normometabolic children and those with lower THS values.

Acknowledgements: This study was conducted as a part of the project No. 1223, entitled: »Investigation of genetically polymorphic proteins and other biomolecules as risk factors for development of atherosclerosis and other diseasesá, financially supported by the Ministry of Science, Technologies and Development, Republic of Serbia. 


\title{
LIPIDNI STATUS U DECE SA HIPOTIREOIDIZMOM: UTICAJ BOLESTI I SUPSTITUCIONE TERAPIJE LEVOTIROKSINOM
}

\author{
Vesna Radonjić1, Zorana Jelić-lvanović2, Slavica Spasić2, \\ Nataša Bogavac-Stanojević2, Vesna Spasojević-Kalimanouska², Božidar Bojović3, Rajko Milunović3 \\ 1Dom zdraulja Kotor, Kotor \\ 2Institut za medicinsku biohemiju, Farmaceutski fakultet, Beograd \\ 3Institut za dečije bolesti, Klinički centar Podgorica, Podgorica
}

\begin{abstract}
Kratak sadržaj: Hipotireoidizam je povezan sa dislipidemijom i povećanim rizikom od ateroskleroze. Cilj ovog rada je bio da se ispita uticaj bolesti i dugoročne supstitucione terapije levotiroksinom (L- $\left.\mathrm{T}_{4}\right)$ na lipidni status dece sa hipotireoidizmom. Određene su koncentracije ukupnog holesterola (TC), HDL-holesterola (HDL-C), LDL-holesterola (LDL-C), triglicerida (TG) i tireostimulirajućeg hormona (TSH) u uzorcima seruma sakupljenim od 58 dece sa hipotireoidizmom (pre i posle terapije) i 100 zdrave dece. Hipotireoidizam je najviše uticao na vrednosti LDL-C i TC: kod pacijenata su nađene prosečno 100\% (LDL-C), odnosno 54\% (TC) više koncentracije nego u kontrolnoj grupi. Ovo se slaže sa poznatom činjenicom da je katabolizam LDL čestica u hipotireoidizmu usporen. Vrednosti TG su bile nešto više $(p<0,05)$, a HDL-C niže $(p<0,02)$, ali samo u nekim starosnim grupama pacijenata. Dugoročna supstituciona terapija imala je najizrazitiji uticaj na nivoe LDL-C i TC: vrednosti dobijene kod pacijenata posle terapije bile su znatno niže nego pre terapije i nisu se značajno razlikovale od koncentracija dobijenih kod zdrave dece odgovarajuće starosti. Značajno niže vrednosti HDL-C i TG posle davanja L-T dobijene su jedino kod dece uzrasta od 10 do 15 godina. Sniženje vrednosti TC i LDL-C pod uticajem L-T 4 bilo je izraženije kod normometaboličnih nego kod hipometaboličnih pacijenata $(p<0,01)$. Kod pacijenata pod terapijom $\mathrm{L}-\mathrm{T}_{4}$, dobijena je dobra korelacija između nivoa TC, odnosno LDL-C pacijenata sa koncentracijom TSH ( $\mathrm{r}=0,770$ i 0,725 , respektivno).
\end{abstract}

Ključne reči: bolesti tireoidee, sekundarna dislipidemija, holesterol, supstituciona terapija.

\section{References}

1. Wu Y, Koenig RJ. Gene regulation by thyroid hormone. TEM 2000; 11: 20711.

2. Duntas HL. Thyroid disease and lipids. Thyroid 2002; 12: 28793 .

3. Feld S, Dickey RA. An association between varying degrees of hypothyroidism and hypercholesterolemia in women: the thyroid-cholesterol connection. Prev Cardiol 2001; 4: 17982.

4. Berti JA, Amaral ME, Boschero AC, Nunes VS, Harada LM, Castilho LN, Oliveira HC. Thyroid hormone increases plasma cholesteroyl ester transfer protein activity and plasma high-density lipoprotein removal rate in transgenic mice. Metabolism 2001; 50: 5306.

5. Tan KCB, Shiu SWM, Kung AWC. Effect of thyroid dysfunction on high-density lipoprotein subfraction metabolism: roles of hepatic lipase and cholesteryl ester transfer protein. J Clin Endocrinol Metab 1998: 83: 29214.

6. Kinlaw WB. Atherosclerosis and the thyroid. Thyroid Today 1991; 14: 18.

7. Verdugo C, Perrot L, Ponsin G, Valentin C, Berthezene F. Time-course of alterations of high-density lipoproteins during thyroxine administration to hypothyroid women. Eur J Clin Invest 1987; 17: 3136.

8. Friis T, Pedersen LR. Serum lipids in hyper- and hypothyroidism before and after treatment. Clin Chim Acta 1987; 162: 15563.
9. Muls E, Rosseneu M, Blaton M, Lesaffre E, Lamberigts G, de Moor P. Serum lipids and apolipoproteins A-I, A-II and $\mathrm{B}$ in primary hypothyroidism before and during treatment. Eur J Clin Invest 1984; 14: 125.

10. O'Brien T, Katz K, Hodge D, Nguyen T, T Kottke BA, Hay ID. The effect of treatment of hypothyroidism and hyperthyroidism on plasma lipids and apolipoproteins AI, AII and E. Clin Endocrinol (Oxf) 1997; 46: 1720.

11. Agdeppa D, Macaron C, Mallik T, Schnuda ND. Plasma high density lipoprotein cholesterol concentration in thyroid disease. J Clin Endocrinol Metab 1979; 49: 7269.

12. Fridewald WT, Levy RI, Frederickson DS. Estimation of the concentration of low-density lipoprotein cholesterol in plasma, without use of the preparative ultracentrifuge. Clin Chem 1972; 18: 499502.

13. National Cholesterol Education Program. Report of the Expert Panel on Blood Cholesterol in Children and Adolescents. Bethesda, MD: National Cholesterol Education Program; 1991.

14. Deschampheleire M, Luyckx FH, Scheen AJ. Thyroid disorders and dyslipidemias. Rev Med Liege 1999; 54 : 74650 .

15. O'Brien T, Dinneen SF, O'Brien PC, Palumbo PJ. Hyperlipidemia in patients with primary and secondary hypothyroidism. Mayo Clin Proc 1993; 68: 8606. 
16. Fisher DA, Schoen EJ, Franchi LA, Mandel SH, Nelson JC. The hypothalamic-pituitary-thyroid negative feedback control axis in children with treated congenital hypothyroidism. J Clin Endocrinol Metab 2000; 85: 27227.

17. Grant DB. Monitoring TSH concentrations during treatment for congenital hypothyroidism. Arch Dis Child 1991; 66: 66970.

18. Heyerdahl S, Kase BF. Significance of elevated serum thyrotropin during treatment of congenital hypothyroiism. Acta Paediatr 1995; 84: 6348.

19. Fruchart JC, Ailhaud G. Apolipoprotein A-containing lipoprotein particles: physiological role, quantification and clinical significance. Clin Chem 1992; 38: 7937.

20. Ilingworth DR, McClung MR, Connor WE, Alaupovic P. Familial hypercholesterolaemia and hypothyroidism: coexistence of both disorders in a young woman with severe hypercholesterolaemia. Clin Endocrinol 1981; 14: 14552.

Received: July 2, 2002

Accepted: October 21, 2002 